Chaolun Allen Chen · Ya-Wen Yang

Nuwei Vivian Wei · Wan-Shen Tsai · Lee-Shing Fang

\title{
Symbiont diversity in scleractinian corals from tropical reefs and subtropical non-reef communities in Taiwan
}

Received: 27 August 2002/ Accepted: 11 June 2003 / Published online: 30 December 2004

(C) Springer-Verlag 2004

\begin{abstract}
We examined zooxanthellae diversity in scleractinian corals from southern Taiwan and the Penghu Archipelago, a tropical coral reef and a subtropical nonreefal community, respectively. Zooxanthellae diversity was investigated in 52 species of scleractinian corals from 26 genera and 13 families, using restriction fragment length polymorphism (RFLP), and phylogenetic analyses of the nuclear small-subunit ribosomal DNA (nssrDNA) and large-subunit ribosomal DNA (nlsrDNA). RFLP and phylogenetic analyses of nuclearencoded ribosomal RNA genes showed that Symbiodinium clade $\mathrm{C}$ was the dominant zooxanthellae in scleractinian corals in the seas around Taiwan; Symbiodinium clade D was also found in some species. Both Symbiodinium clade C and D were found in colonies of seven species of scleractinian corals. Symbiodinium clade D was associated with corals that inhabit either shallow water or the reef edge in deep water, supporting the hypothesis that Symbiodinium clade D is a relatively stress-tolerant zooxanthellae found in marginal habitats.
\end{abstract}

Communicated by Biological Editor H.R. Lasker

C. A. Chen $(\varangle) \cdot$ Y.-W. Yang · N. V. Wei

Institute of Zoology, Academia Sinica, Nankang,

115 Taipei, Taiwan

E-mail: cac@gate.sinica.edu.tw

Tel.: + 886-2-27899549

Fax: + 886-2-27858059

C. A. Chen · N. V. Wei

Institute of Oceanography, National Taiwan University, 106 Taipei, Taiwan

W.-S. Tsai

The Penghu Aquarium, Taiwan Fisheries Research Institute, Makung, 880 Penghu, Taiwan

L.-S. Fang

National Museum of Marine Biology/Aquarium,

Hengchun, 946 Pingtung, Taiwan
Keywords RFLP · Nuclear small-subunit ribosomal DNA · Nuclear large-subunit ribosomal DNA ·

Phylogenetic analysis · Symbiodinium

\section{Introduction}

Hermatypic corals and many reef-associated taxa decline in diversity with increasing distance from the central Indo-West Pacific (Veron 2000). For example, species diversity in hermatypic corals is overwhelmingly high in the Indo-Pacific with uniformity from the Red Sea to Fiji (Veron 1993, 1995, 2000). On the latitudinal scale, the regional distribution of reefbuilding corals is presumably influenced by local physical and environmental constraints. The Kuroshio Current originates in the northern Philippines, enters the East China Sea through the Taiwan Strait and the Yaeyama Islands, and flows northwards to the Ryukyu Islands (Veron and Minchin 1992; reviewed in Veron 1995, 2000). This current, in combination with the effect of sea surface temperature limits, has divided the hermatypic corals in these areas into three groups: tropical reefs, non-reefal communities, and high-latitude outlying populations (Veron and Minchin 1992; Veron 1993, 1995, 2000).

While geographic diversity or latitudinal distribution patterns of hermatypic corals have been ascribed to the effects of physical and environmental constraints, the regional diversity of the photosynthetic symbionts of hermatypic corals, the zooxanthellae, are just beginning to receive attention (Baker and Rowan 1997; Loh et al. 2001; Rodriguez-Lanetty et al. 2001). Zooxanthellae are golden, brown, or yellow dinoflagellates. They play an important role in the ecology of coral reefs through their contribution to host nutrition and the deposition of calcium carbonate to build reefs in shallow, nutrientpoor tropical seas (reviewed in Muscatine and Porter 1977; Falkowski et al. 1984; Barnes and Chalker 1990; Muller-Parker and D'Elia 1997). 
Traditionally, zooxanthellae were thought to be a single pandemic species, Symbiodinium microadriaticum (Freduenthal) (Taylor 1974), but subsequent studies have indicated that zooxanthellae are a highly diverse array of symbiotic dinoflagellates (reviewed in Trench 1997; Rowan 1998). Molecular methods, including restriction fragment length polymorphism (RFLP), DNA sequencing of nuclear small-subunit ribosomal DNA (nssrDNA), nuclear large-subunit rDNA (nlsrDNA), internal transcribed spacer (ITS) rDNA, and chloroplast large-subunit rDNA (clsrDNA), have revealed a diverse array of symbionts (Rowan and Powers 1991a, 1991b; Rowan and Knowlton 1995; Baker and Rowan 1997; Baker et al. 1997; Hunter et al. 1997; Rowan et al. 1997; Wiclox 1998; Carlos et al. 1999; Baillie et al. 2000; LaJeunesse 2001; Pochon et al. 2001; Toller et al. 2001a, 2001b; van Oppen et al. 2001; Santos et al. 2002). Currently four clades, Symbiodinium A, B, C, and D/E, are recognized to be associated with scleractinian corals (Rowan and Powers 1991a; Rowan and Knowlton 1995; LaJeunesse 2001; Loh et al. 2001; Pawloski et al. 2001; Pochon et al. 2001; Toller et al. 2001a; Santos et al. 2002). Symbiodinium $\mathrm{D} / \mathrm{E}$ may represent different clades since the investigators who characterized them used different genetic markers (Carlos et al. 1999; Baillie et al. 2000; LaJeunesse 2001; Loh et al. 2001; Pochon et al. 2001; Toller et al. 2001a, 2001b; van Oppen et al. 2001; Santos et al. 2002), but phylogenetic analyses have indicated that they should belong to the same clade of zooxanthellae (see "Results"). In addition, clade E possesses the same nssr-rDNA RFLP pattern as isolate PSP1-105 in Carlos et al. (1999) and, therefore, should have been placed within Symbiodinium clade D. Herein we use Symbiodinium clade D as nominated by Carlos et al. (1999) to avoid confusion.

Host-symbiont relationships were initially believed to be highly specific; however, later work revealed not only the occurrence of multiple strains within hosts, but also diverse ecological factors driving ecological zonation of different strains among coral colonies and even over the surface of individual coral colonies (Rowan and Knowlton 1995; Rowan et al. 1997; Baker 2001; Toller et al. 2001a, 2001b). Zooxanthellae diversity thus provides a mechanism for corals to adapt to changing environmental conditions (Rowan et al. 1997; Baker 2001). Since environmental factors may vary enormously from location to location and from time to time, regional differences in zooxanthellae diversity within a single host or among multiple species are therefore important (Baker and Rowan 1997). In Plesiastrea versipora, colonies collected from tropical and subtropical Australia contained symbionts belonging to Symbiodinium clade $\mathrm{C}$, while $P$. versipora colonies at high-latitude sites contained Symbiodinium B (Rodriguez-Lanetty et al. 2001). For Acropora longicyathus, 7 of 11 of the Australian, and all Japanese and Malaysian colonies were associated with Symbiodinium clade C, but symbionts from the remaining Australian A. longicyanthus were Symbiodinium clade A. Symbionts from Australian and Japanese Seriatopora hystrix were identified as Symbiodinium clade C, while Malaysian S. hystrix symbionts were Symbiodinium clade D (Loh et al. 2001). Among the four clades of Symbiodinium, Symbiodinium clade D was hypothesized to be tolerant to stress because it is found in marine habitats with high environmental disturbance (e.g., fluctuations in temperature, salinity, nutrients, or sediments) or on very deep reef edges (Toller et al. 2001a). These studies suggest that geographically distinct varieties of symbionts within tissues of scleractinian corals are likely to be: (1) associated with differences in algal physiology; (2) correlated with differences in the dispersal ranges of coral; or (3) symbiont propagules and to be associated with their respective modes of symbiont transmission (Loh et al. 2001; Rodriguez-Lanetty et al. 2001).

Taiwan, a continental island with several offshore islets, is located at the center or junction of the Philippine-Japan island arc. The Taiwan Strait, situated to the west and separating Taiwan from mainland China by about $90 \mathrm{~km}$, is a shallow channel with sandy or muddy habitats. The occurrence of scleractinian corals in Taiwan is influenced by sea surface currents and seawater temperatures (Fig. 1; for review and references see Chen 1999). The northern, northeastern, and rocky eastern coasts have flourishing or patchy coral communities, but reef development is generally absent (reviewed in Dai 1997). Southern Taiwan is surrounded by well-developed fringing reefs inhabited by a relatively rich coral fauna (reviewed in Dai 1997). Lutao (Green Island) and Lanyu (Orchid Island), located off southeastern Taiwan, are situated in the pathway of the warm Kuroshio Current. The Penghu Archipelago (Penghu or the Pescadores) is composed of 64 islets and is divided into four regions, southern (SP), northern (NP), eastern (EP), and inner (IP), according to previous reports (Fig. 1a; reviewed in Chen 1999). Analysis of species composition of Acropora and Faviidae in the four major reef systems of Kenting, Green Island, Penghu, and the Northeast Coast of Taiwan suggests two distinct provinces of scleractinian distribution (Kenting and Green Island, and Penghu and the Northeast Coast), which is congruent with sea surface temperatures and currents around Taiwan (Fig. 1, Chen 1999). Two major coral communities, tropical reefs and a subtropical non-reefal community, can be separated according to the characteristics of these two provinces. This pattern is also congruent with those documented for reef fishes around Taiwan, i.e., the "Kuroshio-affected zone" and the "southwestern monsoon-affected zone" (Shao et al. 1994). In addition, the higher gene flow found between Mycedium elephantotus populations in northern Taiwan and Penghu than that between populations in southern Taiwan and other regions, is consistent with the pattern of ocean currents around Taiwan ( $\mathrm{Yu}$ et al. 1999). Whether zooxanthellae show differences in composition or diversity between Penghu and southern Taiwan as is seen in their hosts is worthy of further investigation. In the present study, we used RFLP and phylogenetic 
Fig. 1 A Map of Taiwan and neighboring islets, including an enlarged detail of the Penghu Archipelago, showing current systems and minimum winter seawater temperatures around the island. Sea surface currents and their directions are indicated as different arrow patterns: Bold line: Kuroshio Current; dashed line: South China Sea surface current; dotted line: China coastal water. B The parsimonious tree derived from the combined presence/absence matrices of Acropora and Faviidae (redrawn from Chen 1999). Current systems correlated with reef systems are indicated at the end of the tree. $N E$ northeastern Taiwan; NP northern Penghu; $I P$ inner Penghu; EP eastern Penghu; $S P$ southern Penghu; GI Green Island; KT Kenting
(A)

(B)

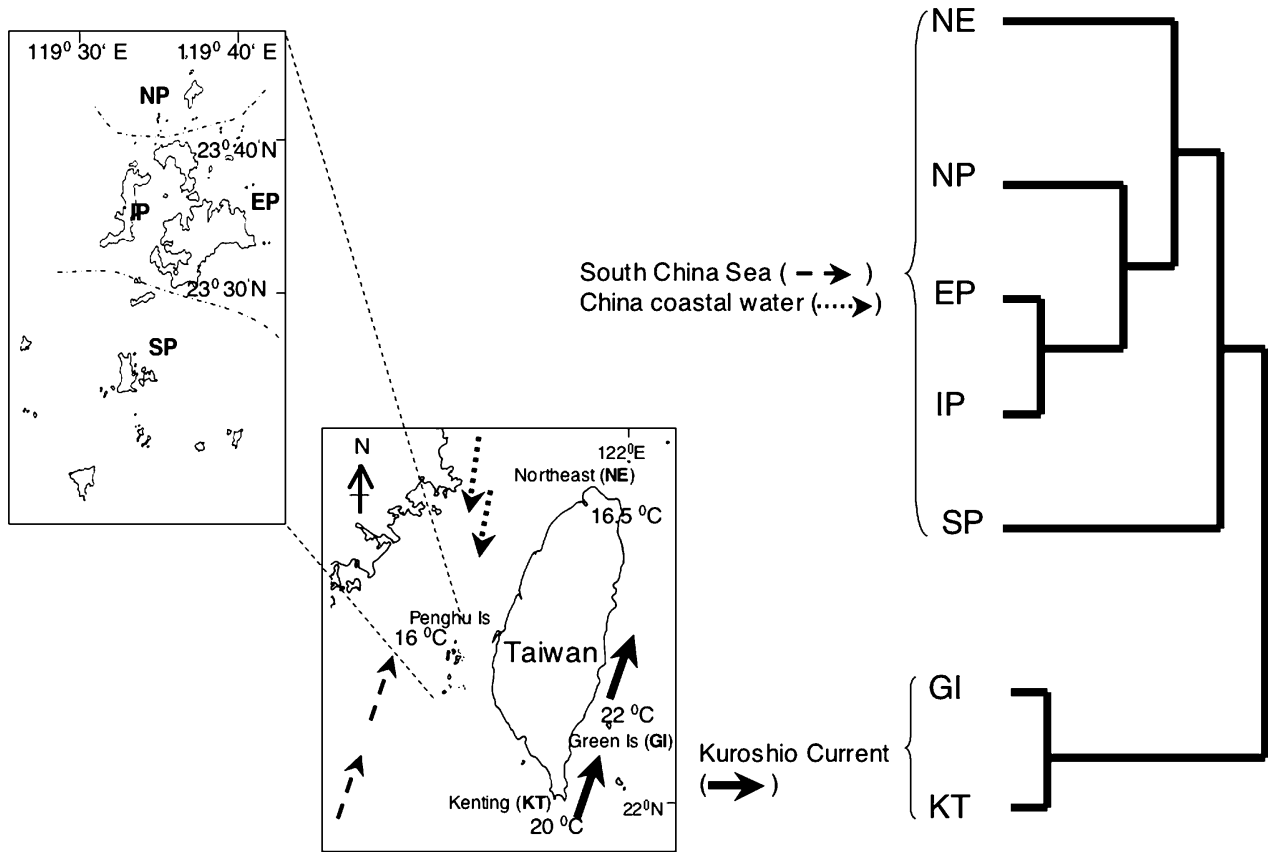

analyses of nssrDNA and nlsrDNA sequences to examine zooxanthellae diversity in 52 species of scleractinian corals collected from Kenting, southern Taiwan, and Penghu.

\section{Materials and methods}

Field collections

Scleractinian samples were collected at a depth of 0-15 $\mathrm{m}$, from fringing reefs of southern Taiwan and the Penghu Archipelago between 1997 and 2001 (Fig. 1, Table 1). Fragments of coral samples were placed in labeled bags, and preserved in $95 \%(\mathrm{v} / \mathrm{w})$ ethanol immediately after collection.

Identification of zooxanthellae

DNA extraction was modified from methods described by Chen and $\mathrm{Yu}(2000)$ and Chen et al. (2000). Two sets of genetic markers, nuclear small-subunit ribosomal DNA (nssrDNA) and nuclear large-subunit DNA (nlsrDNA), were used to assay zooxanthellae diversity. At the initial stage of this study, we used nssrDNA to visualize the classical genotypes defined by Rowan and Powers (1991a), Rowan and Knowlton (1995), and Toller et al. (2001a). nssrDNA was obtained by PCR amplification with a host-excluding primer pair (ss5z: 5'GCAGTTATAR TTTATTTGAT GGTYRCTGCT AC-3'; and ss3z: 5'-AGCACTGCGT CAGTCCGAAT AATTCACCGG-3), and then characterized using the restriction enzymes, $\operatorname{Sau} 3 A$ I and Taq I, which differ- entiate four clades of Symbiodinium, A, B, C, and D (Rowan and Powers 1991a; Toller et al. 2001a). The 5 '-end of the nlsrDNA was amplified using a hostexcluding primer pair (5S: 5'-GCCGACCCGCTGAATTCAAGCATAT-3'; and D23zoox: 5'-TGTGGCAYGTGACGCGCAAGCTAAG-3') and then characterized using the restriction enzyme, $R s a$ I. $R s a$ I was chosen based on the restriction map from the alignment of the nlsrDNA sequences of four Symbiodinium clades available from GenBank. All enzymes were purchased from MBI (Fermantas). Subsequently, PCR fragments of nssrDNA and nlsrDNA gene products were then cloned and sequenced as described in Chen et al. (2000). DNA sequences obtained from this study were deposited in GenBank with accession numbers listed in Table 1.

Sequence alignment and phylogenetic analysis

DNA sequences were initially aligned using CLUSTAL W 1.7 (Thompson et al. 1994), followed by manual editing using SeqApp 1.9 (Gilbert 1994). We used only partial nssrDNA sequences (V2 and V4 domains) following the instructions of Rowan and Power (1991b), Rowan and Knowlton (1995), and Toller et al. (2001a), and the 5'-end of nlsrDNA sequences for phylogenetic reconstructions. The aligned sequences used in this study were submitted to TreeBase (http://www.treebase.org). Phylogenetic analyses were performed using PAUP 4.0b10 (Swofford 2002). Maximum-parsimony (MP) analyses were performed by heuristic searches, with 100 random additions of sequences, to search for the most-parsimonious trees. Bootstrapping with 1,000 pseudoreplicates and a heuristic search were used to 
Table 1 Taxonomic information, sampling sites, RFLP markers, Symbiodinium clades, collecting depth, and GenBank accession numbers of zooxanthellae isolated from scleractinian corals collected in southern Taiwan $(K T)$ and Penghu $(P I)$

\begin{tabular}{|c|c|c|c|c|c|c|c|}
\hline Host species & Site & $\begin{array}{l}\text { nssrDNA } \\
\text { RFLP }\end{array}$ & $\begin{array}{l}\text { nlsrDNA } \\
\text { RFLP }\end{array}$ & $\begin{array}{l}\text { Symbiodinium } \\
\text { Clade }\end{array}$ & Depth (m) & $\begin{array}{l}\text { nssrDNA } \\
\text { GenBank } \\
\text { Accession no. }\end{array}$ & $\begin{array}{l}\text { lssrDNA } \\
\text { GenBank } \\
\text { Accession no. }\end{array}$ \\
\hline
\end{tabular}

Family Acroporidea Acropora digitifera (5)

A. gemmifera (5)

A. humilis (5)

(10)

A. hyacinthus (5)

(9)

A. intermedia (5)

(5)

A. latistella (5)

A. muricata (5)

A. palifera $(>50)$

A. pulchra (5)

A. tenuis (5)

A. valida (7)

A. yongei (2)

(1)

Astreopora myriophthalma (5)

Montipora cactus (14)

(1)

Montipora aequituberculata (5)

Montipora digitata (5)

M. efflorescens (3)

M. hispida (5)

M. spongodes (4)

M. undata (2)

Montipora sp. (1)

Family Astrocoeniidae

Stylocoeniella guentheri (1)

Family Pocillopridae

Stylophora pistillata (5)

(4)

Pocillopora damicornis (20)

(30)

Family Euphyllidae

Euphyllia ancora (6)

(3)

Euphyllia paraancora (20)

E. glabrescens (5)

Family Poritidae

Porites cylindrica (5)

P. lutea (5)

(2)

P. solida (1)

Goniopora columna (2)

G. lobata (4)

Family Siderastreidae

Pseudosiderastrea tayamai (5)

Family Agariciidae

Pavona decussata (3)

Pavona frondifera (8)

Pavona varians (1)

Pavona venosa (2)

Family Fungiidae

Lithophyllon undulatum (4)

Family Oculinidae

Galaxea fascicularis (5)

Family Pectiniidae

Echinophyllia orpheensis (2)

Mycediun elephantotus (1)

$\begin{array}{ll}\mathrm{KT} & + \\ \mathrm{KT} & + \\ \mathrm{KT} & + \\ \mathrm{PI} & + \\ \mathrm{KT} & + \\ \mathrm{PI} & + \\ \mathrm{KT} & + \\ \mathrm{PI} & + \\ \mathrm{KT} & + \\ \mathrm{PI} & + \\ \mathrm{KT} & +\end{array}$

+
+
+
+
+

$\mathrm{C}_{3}$

3-5

$\mathrm{C}_{3} \quad 3-5$

$\mathrm{C}_{3} \quad 3-5$

$\mathrm{C}_{3} \quad 1-3$

$\mathrm{C}_{3} \quad 3-10$

$\mathrm{C}_{3} \quad 3-5$

$\mathrm{C}_{3} \quad 5-10$

$\mathrm{C}_{3} \quad 3-5$

$\mathrm{C}_{3} \quad 8-12$

$\mathrm{C}_{3} \quad 1-5$

$\mathrm{C}_{1} / \mathrm{C}_{3} \quad 0-3$

$\mathrm{D}_{1} / \mathrm{D}_{2}$

$\mathrm{C}_{1}+\mathrm{D}_{1} / \mathrm{C}_{3}+\mathrm{D}_{2}$

$\mathrm{C}_{3} \quad 5-8$

$\mathrm{C}_{3} \quad 5-8$

$\mathrm{C}_{3} \quad 3-5$

$\mathrm{C}_{3} \quad 3-5$

$\mathrm{C}_{3}+\mathrm{D}_{1}$

$\mathrm{C}_{1} \quad 3-6$

$\mathrm{C}_{1} \quad 0-3$

$\mathrm{C}_{1}+\mathrm{D}_{1}$

$\mathrm{C}_{1} \quad 3-5$

$\mathrm{C}_{1} \quad 3-5$

$\mathrm{C}_{1} \quad 3-5$

$\mathrm{C}_{1} \quad 3-5$

$\mathrm{C}_{1} \quad 3-5$

$\mathrm{C}_{1}-3-5$

$\begin{array}{llll}\mathrm{PI}+ & + & \mathrm{C}_{1} & 3-5 \\ \mathrm{KT} & + & \mathrm{C}_{1} & 3\end{array}$

PI $+\mathrm{C}_{1} \quad 5$

$\mathrm{KT}+\mathrm{C}_{1}-3-5$

PI $+\mathrm{C}_{1} \quad 3-5$

$\mathrm{KT}+\quad+\quad \mathrm{C}_{1} / \mathrm{C}_{2} \quad 0-5$

$\mathrm{PI}+\quad+\quad \mathrm{C}_{1} / \mathrm{C}_{2} \quad 0-5$

$12-15$

AY051109

AY139265

AY139241

AY051111

AY139265

AY051107

AY139260

AY139192-95 AY139261-64

AY139230-33

AY139235

AY139228 $\left(D_{1}\right)$

AY051100

AY051098

AY139253

$\mathrm{AY} 051099\left(\mathrm{D}_{1}\right)$

AY051102

AY139267

AY051110

AY139252

$\mathrm{KT}+$

$+$

$\mathrm{C}_{1}$

$\mathrm{C}_{1}+\mathrm{D}_{1}$

$\mathrm{PI}+\mathrm{C}_{1}+\mathrm{D}_{1}$

$8-12$

$\mathrm{C}_{1}$

3-5

$\mathrm{C}_{1}$

$\mathrm{C}_{1}$

$\mathrm{C}_{1}$

$\mathrm{C}_{1}$

$\mathrm{C}_{1}$

$\mathrm{C}_{1}$

$\mathrm{KT}+\mathrm{C}_{1} \quad 2-3$

4-6

4-6

2-4

4

2-5

$2-5$

AY139254

AY139244(C $\left.\mathrm{C}_{2}\right)$

AY051090-95

AY1392637/AY139257

AY139225/AY139239

AY 139250

AY139249

AY139248

AY139234

PI $+\mathrm{C}_{1} \quad 3-5$

$\mathrm{PI}+\quad+\quad \mathrm{C}_{1} \quad 3-5$

KT

$\mathrm{C}_{1}$

$\mathrm{C}_{1}$

3

3

$+$

$\mathrm{C}_{1}$

2-4

AY139244

AY139243

AY139242

AY139259

AY139258

AY139251

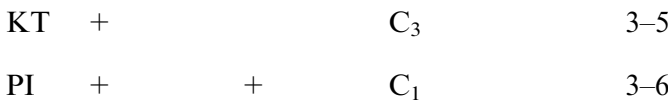

$\begin{array}{ll}\mathrm{C}_{1} & 4\end{array}$
$3-6$
4 
Table 1 (Contd.)

\begin{tabular}{|c|c|c|c|c|c|c|c|}
\hline Host species & Site & $\begin{array}{l}\text { nssrDNA } \\
\text { RFLP }\end{array}$ & $\begin{array}{l}\text { nlsrDNA } \\
\text { RFLP }\end{array}$ & $\begin{array}{l}\text { Symbiodinium } \\
\text { Clade }\end{array}$ & Depth (m) & $\begin{array}{l}\text { nssrDNA } \\
\text { GenBank } \\
\text { Accession no. }\end{array}$ & $\begin{array}{l}\text { lssrDNA } \\
\text { GenBank } \\
\text { Accession no. }\end{array}$ \\
\hline \multicolumn{8}{|l|}{ Family Merulinidae } \\
\hline Merulina ampliata (5) & KT & + & & $\mathrm{C}_{1}$ & $3-6$ & & \\
\hline (4) & PI & & + & $\mathrm{C}_{1}$ & 6 & & \\
\hline Hydnophora exesa (3) & PI & & + & $\mathrm{C}_{1}$ & $3-5$ & & AY139255 \\
\hline \multicolumn{8}{|l|}{ Family Faviidae } \\
\hline Favia favus (5) & KT & + & & $\mathrm{C}_{1}$ & $3-6$ & & \\
\hline Favites abdita (5) & KT & + & & $\mathrm{C}_{1}$ & $1-3$ & & \\
\hline $\begin{array}{l}(3) \\
(1)\end{array}$ & PI & + & + & $\begin{array}{l}\mathrm{C}_{1} \\
\mathrm{C}_{1}+\mathrm{D}_{1}\end{array}$ & $1-3$ & & AY139238 \\
\hline Goniastrea retiformis (1) & KT & & + & $\mathrm{C}_{1}$ & 3 & & AY139246 \\
\hline Leptoria phrygia (1) & KT & & + & $\mathrm{C}_{1}$ & 3 & & AY139266 \\
\hline Montastrea curta (2) & PI & + & + & $\mathrm{C}_{1}$ & $3-5$ & & \\
\hline Montastrea valenciennesi (3) & KT & & + & $\mathrm{C}_{1}$ & $3-5$ & & $\begin{array}{l}\text { AY139240 } \\
\text { AY139247 }\end{array}$ \\
\hline Plesiastrea versipora (5) & PI & + & + & $\mathrm{C}_{1}$ & $3-5$ & AY051096 & \\
\hline Oulastrea crispata $(>50)$ & PI & & + & $\mathrm{D}_{1}$ & $0-2$ & AY051097 & $\begin{array}{l}\text { AY139226/ } \\
\text { AY139227/AY139229 }\end{array}$ \\
\hline $\begin{array}{l}\text { Echinopora lamellosa (3) } \\
\text { Family Dendrophylliidae }\end{array}$ & PI & + & + & $\mathrm{C}_{1}$ & $3-6$ & & \\
\hline $\begin{array}{l}\text { Turbinaria mesenteria (1) } \\
\text { (3) }\end{array}$ & PI & + & & $\begin{array}{l}\mathrm{C}_{1} \\
\mathrm{C}_{1}+\mathrm{D}_{1}\end{array}$ & $8-12$ & & AY139224/AY139236 \\
\hline
\end{tabular}

examine the robustness of clades in the resulting trees. For the neighbor-joining (NJ) analysis, the best-fit model of DNA substitution and the parameter estimates used for tree construction were chosen by performing hierarchical likelihood ratio tests using PAUP 4.0b10 and Modeltest 3.06. Likelihood-ratio tests indicated that the F81 model with a gamma distribution-shaped parameter of 1.6296 was most appropriate for both nssrDNA and nlsrDNA in the subsequent NJ analyses. The robustness of the NJ phylogenies was assessed using the 1,000 bootstrap option.

\section{Results}

RFLP analysis

On the basis of RFLP analysis of nssrDNA and nslrDNA, we detected very little variation among more than 400 individual zooxanthellae isolates from 52 species of scleractinian corals collected at various locations off southern Taiwan and Penghu (Table 1). The RFLP patterns of nssrDNA we found fit those of Symbiodinium clade $\mathrm{C}$ and clade $\mathrm{D}$ as described by Rowan and Powers (1991a), Rowan and Knowlton (1995), and Toller et al. (2001a). With the exception of isolates from Oulastrea crispata, all scleractinian corals were found to contain Symbiodinium clade C, although some were mixed with Symbiodinium clade D (see below). There were three genotypes in Symbiodinium clade $\mathrm{C}$ based on the nssrDNA RFLP patterns: genotype $C_{1}$ had 890/ $710 \mathrm{bp}$ for Taq I and 865/500 bp for Sau 3AI (Yu et al. 2000; Fig. 2, lane 2). A variant genotype, $C_{2}$, was found in Pocillopora damicornis with two restriction sites forming fragments of 710/540/350 bp for Taq I and 865/ $500 \mathrm{bp}$ for Sau 3AI (Yu et al. 2000, Fig. 1, lane 3). Genotype $\mathrm{C}_{3}$ was found in 12 Acropora species and Galaxea fascularis, with $890 / 710$ bp for Taq I and 865/ 555 bp for Sau 3AI (Fig. 2, lane 2). Fragments smaller than 200 bp in length could not be observed in Sau 3A I digestions of nssrDNA PCR products due to limitations of the agarose gels. The Rsa I RFLP pattern (320/ $200 \mathrm{bp}$ ) of nlsrDNA was identical among the three genotypes of Symbiodinium C (Fig. 1C).

The zooxanthellae isolated from Acropora palifera and Euphyllia ancora in Kenting; and A. youngi, E. paraancora, Montipora cactus, O. crispata, and Turbinaria mesenteria in Penghu contained Symbiodinium clade D (Fig. 2, Table 1). Two genotypes, $\mathrm{D}_{1}$ and $\mathrm{D}_{2}$, were identified from freshly isolated zooxanthellae by nssrDNA RFLP. $\mathrm{D}_{1}$, with $865 / 500$ bp for Sau 3AI and $730 / 710$ bp for $T a q$ I, was found in six of the seven coral species listed above, excluding A. palifera (Fig. 2, lane 4). This digestion pattern was previously detected in zooxanthellae from Montipora patula (Rowan and Powers 1991b), and was classified as the RFLP type D3 (Rowan and Powers 1991a). However, we assigned isolates with this digestion pattern to Symbiodinium clade D on the basis of nucleotide phylogenetic analyses (Fig. 3). $\mathrm{D}_{2}$ was identified in zooxanthellae isolated from $\mathrm{A}$. palifera with an RFLP pattern of 900/865/500 bp for Sau 3AI, and 740/730/710 bp for Taq I (Fig. 2, lane 5). Furthermore, by cloning Symbiodinium clade D zooxanthellae from Acropora palifera, two sizes of PCR products were identified. The larger PCR product of genotype $\mathrm{D}_{2}$ was $1,669 \mathrm{bp}$ (GenBank accession no. 

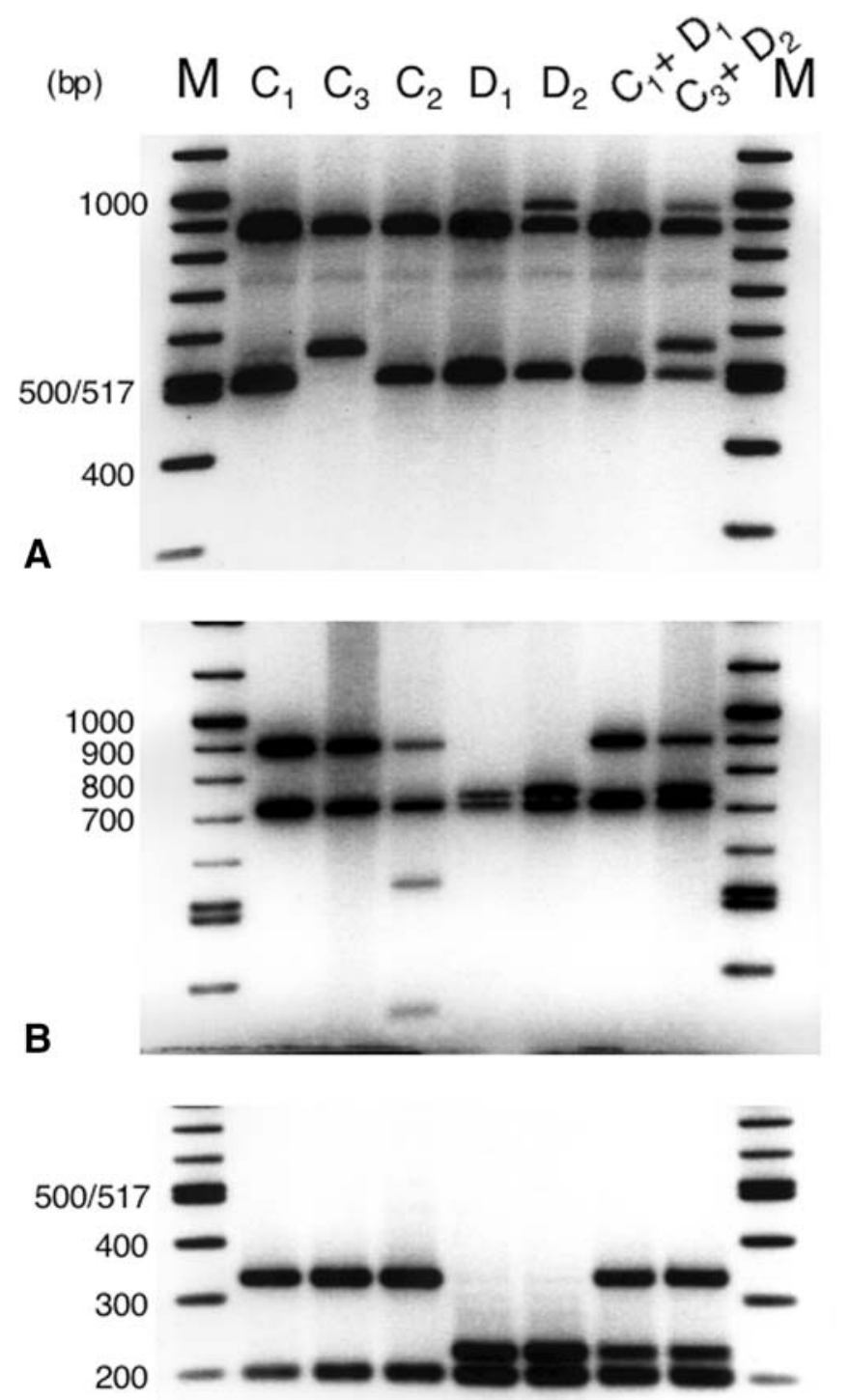

C

100

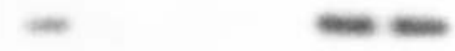

Fig. 2 RFLP genotyping of zooxanthellae freshly isolated from several examples of scleractinian corals in Kenting and Penghu. PCR products of nuclear small-subunit ribosomal DNA (nssrDNA) were digested with either Taq I ( A) or Sau 3AI ( B). C PCR products of nuclear large-subunit ribosomal DNA (nlsrDNA) were digested with Rsa I. Lanes at both ends of the gels labeled with $M$ are DNA fragment size standards of a 100-bp DNA ladder. Lanes 1, 2, and 3 are Symbiodinium clade C isolated from Euphyllia ancora, Acropora palifera, and Pocillopora damicornis, respectively. Lanes 4 and 5 are Symbiodinium clade D isolated from Oulastrea crispata and A. palifera, respectively. Lanes 6 and 7 are mixtures of Symbiodinium clade C and D isolated from $E$. ancora and $A$. palifera, respectively

AY139193), compared with 1,595 bp for the $D_{1}$ genotype (GenBank accession no. AY139194-5). Based on the secondary structure of the ssrRNA gene of Symbiodinium pilosum, the $\mathrm{D}_{2}$ genotype has additional bases inserted at positions $252-253$ and $320-321$ in the stem (data not shown). These two variants of Symbiodinium clade D consistently occurred in the A. palifera sampled in this study, and could be identified by Sau 3AI digestion patterns (Fig. 2). Oulastrea crispata was only associated with Symbiodinium $\mathrm{D}_{1}$.

\section{Phylogenetic analyses}

The outgroup sequences used in the phylogenetic analyses were Gymnodinium beii and G. simplex. The phylogenetic positions of the zooxanthellae isolates were inferred by analyzing the hypervariable V2 and V4 regions of nssrDNA (450 bp) and the 5'-end of nlsrDNA (436 bp), respectively. NJ and MP phylogenetic reconstruction methods were used to analyze both sets of DNA sequences. All of the phylogenetic analyses showed high bootstrap support for the major clade groupings, and demonstrated that there were four major clades of zooxanthellae: Symbiodinium clade A, B, C, and D (Fig. 3). Consistent with the patterns found for RFLP products, most isolates belonged to Symbiodinium clade $\mathrm{C}$, with the exception of samples from Acropora palifera, A. youngi, Euphyllia anacora, Montipora cactus, Oulastrea crispata, and Turbinaria mesenteria which contained Symbiodinium clade D (Fig. 3).

\section{Symbiosis polymorphism}

Symbiosis polymorphism describes the pattern in which scleractinian corals, or single coral colonies, host multiple clades of zooxanthellae (Rowan and Knowlton 1995; Baker and Rowan 1997; Rowan et al. 1997; Baker 2001; Toller et al. 2001a). Results of digestion patterns from isolated zooxanthellae and phylogenetic analyses revealed two combinations of symbiosis polymorphism within individual hosts. The first type of symbiosis polymorphism consisted of zooxanthellae from the same clade having two distinct genotypes. These two genotypes always co-occurred in the same host colony. In Acropora palifera, there were two genotypes of Symbiodinium clade $\mathrm{D}$ : genotypes $\mathrm{D}_{1}$ and $\mathrm{D}_{2}$ (Fig. 3). In Pocillopora damicornis, two Symbiodinium clade C were evident in Taq I digestion patterns: one consisted of genotypes $\mathrm{C}_{1}$ and $\mathrm{C}_{2}$ (Yu et al. 2000). The second type of symbiosis polymorphism was comprised of corals which contained two distinct clades of zooxanthellae, i.e., Symbiodinium clade C and D. This type of symbiosis polymorphism was observed in A. palifera, A. youngi, Euphyllia ancora, E. paraancora, Favites abidata, Montipora cactus, and Turbinaria mesenteria (Table 1).

Diversity of zooxanthellae in scleractinian corals of southern Taiwan and Penghu

We examined differences in zooxanthellae diversity in scleractinian corals of southern Taiwan and Penghu using two approaches. First, we compared zooxanthellae 
associations of the same species which occur at both sites. Among the eight species, including Acropora humilis, A. hyacinthus, A. intermedia, Montipora efflorescens, Stylophora pistellata, Porites lutea, Merulina ampliata, and Favites abidata, seven species were associated with Symbiodinium clade C at both sites. Among the $F$. abidata 1 colony from Penghu contained both Symbiodinium clade C and D (Table 1). In addition, we compared the overall diversity at the "clade" level between the two sites. In total, 31 scleractinian species were surveyed in southern Taiwan, among which 29 species harbored Symbiodinium clade C, and 2 species harbored both Symbiodinium clade C and D (Table 2). In total, 28 scleractinian species were surveyed in Penghu, among which 22 species harbored Symbiodinium clade C, 1 species harbored $\mathrm{D}$, and 5 species harbored a mixture of $\mathrm{C}$ and $\mathrm{D}$ (Table 2). There was no significant difference in zooxanthellae diversity of scleractinian corals between these two communities ( $X^{2}$ test $=2.742$, d.f. $=2, p$ $>0.05)$.

\section{Discussion}

\section{Zooxanthellae diversity in Taiwan}

No apparent variation in zooxanthellae diversity at the clade level was detected in scleractinian hosts between southern Taiwan and Penghu, despite the differences in scleractinian species composition and physical environmental characteristics between the two sites (Dai 1997; Chen 1999). Southern Taiwan is characterized by welldeveloped fringing tropical reefs with approximately 300 known species of scleractinian corals, while only 110 scleractinian species have been recorded in the coral communities of Penghu (Dai 1997). Average monthly water temperatures range from 22.5 to $28.2{ }^{\circ} \mathrm{C}$ in southern Taiwan (Dai 1991); in contrast, water temperatures can fluctuate from 16 to $28^{\circ} \mathrm{C}$ at Penghu. With the influences of different current systems and local environmental disturbances (e.g., temperature, sediment, and irradiance), scleractinian corals and reef fishes show distinct distribution patterns between southern Taiwan and Penghu (Shao et al. 1994; Chen 1999). Nevertheless, not only do the same scleractinian species collected from these two sites contain the same clade of zooxanthellae (except for one colony of Favites abidata in Penghu which contained two clades), but at the community level, 45 of the 52 scleractinian species hosted Symbiodinium belonging to a single clade, C. Although 6 of the 28 Penghu species hosted Symbiodinium clade D, for 3 of those 6, Acropora youngi, Favites abidata, and Montipora cactus, only 1 colony contained Symbiodinium clade D, suggesting that Symbiodinium clade $\mathrm{C}$ is the dominant clade of zooxanthellae in those species.

Several alternative hypotheses can explain the low zooxanthellae diversity observed in this study. First, low variation in zooxanthellae associations might represent the true diversity in these regions, despite one site containing tropical reefs, and the other a subtropical nonreefal community. In a widespread species, Plesiastrea versipora, colonies collected from tropical and subtropical Australia contained symbionts belonging to Symbiodinium clade C, while P. versipora colonies at high-latitude sites contained Symbiodinium clade B (Rodriguez-Lanetty et al. 2001). This result implies that geographically distinct varieties of symbionts within scleractinian corals are likely to be associated with algal physiological differences (Rodriguez-Lanetty et al. 2001), suggesting that Symbiodinium clade C might be capable of coping with differences between tropical and subtropical environments as found in southern Taiwan and Penghu. Second, the low zooxanthellae variation found in the 52 species of scleractinian corals of Taiwan might, indeed, reflect the characteristics of low zooxanthellae diversity in the Pacific. Studies of zooxanthellae diversity in the Pacific scleractinian corals are scattered in the literature (Rowan and Powers 1991a, 1991b; Baker and Rowan 1997; Darius et al. 2000; LaJeunesse 2001; Loh et al. 2001; Pawloski et al. 2001; Pochon et al. 2001; Rodriguez-Lanetty et al. 2001; van Oppen et al. 2001; Santos et al. 2002); however, those results indicate that Symbiodinium clade A and B, which are common in Caribbean scleractinian corals (Rowan and Powers 1991a, 1991b), are rare in the Pacific, and that Symbiodinium clade $\mathrm{C}$ is the major clade of zooxanthellae associated with scleractinian corals in the Pacific. Although the 31 species of scleractinian corals investigated from southern Taiwan and the 28 from Penghu represented only about $1 / 10$ and $1 / 5$ of the scleractinian species in each respective locality, increasing the number of scleractinian taxa sampled is unlikely to increase the number of observed zooxanthellae clades due to regional homogeneity in the Pacific.

Second, the resolution of zooxanthellae diversity might have been limited by the genetic markers used in this study. Although nssrDNA and nlsrDNA RFLP and DNA sequences have confirmed four distinct clades (A, B, C, and D), some within-clade genotypes (Fig. 2) exist for zooxanthellae in scleractinian corals (reviewed in Rowan 1998; Yu et al. 2000; Toller et al. 2001a), and these have successfully resolved the different zooxanthellae clades associated within the same hosts from distant geographic localities (Loh et al. 2001; RodriguezLanetty et al. 2001). These two markers did not adequately resolve the phylogenetic relatedness between genetic types within each of the major phylogenetic lineages (Fig. 3). This was due to the conserved nature of these two ribosomal-encoding genes (reviewed in Hillis and Dixon 1991). In contrast, within-clade diversity, especially in Symbiodinium clade C, has been demonstrated to be high by other rapidly evolving markers, such as ITS (Hunter et al. 1997; LaJeunesse 2001; van Oppen et al. 2001) and clsrDNA (Santos et al. 2002), suggesting that ITS and clsrDNA are suitable markers to further resolve the genetic diversity of Symbiodinium clade $\mathrm{C}$ in the scleractinian corals around Taiwan. 
Fig. 3 Phylogenetic analysis derived from the maximumparsimony $(M P)$ and neighborjoining $(N J)$ algorithms of $(A)$ the V2 and V4 hypervariable regions of the nssrRNA gene $(450 \mathrm{bp})$, and $(B)$ the 5 '-end of the nlsrRNA gene (436 bp) from Symbiodinium isolates. Isolates sequenced in this study are indicated by their host species name and GenBank accession numbers. Reference sequences from GenBank are included and are indicated by their accession numbers. Numbers above and below the branches indicate the bootstrap values for $M P(1,000$ replicates $)$ and $N J$ (1,000 replicates) analyses. Symbiodinium clade $A, B, C$, and $D$ corresponding to RFLP-resolvable genotypes are indicated. Gymnodinium beii and $G$. simplex were used for outgroup comparison

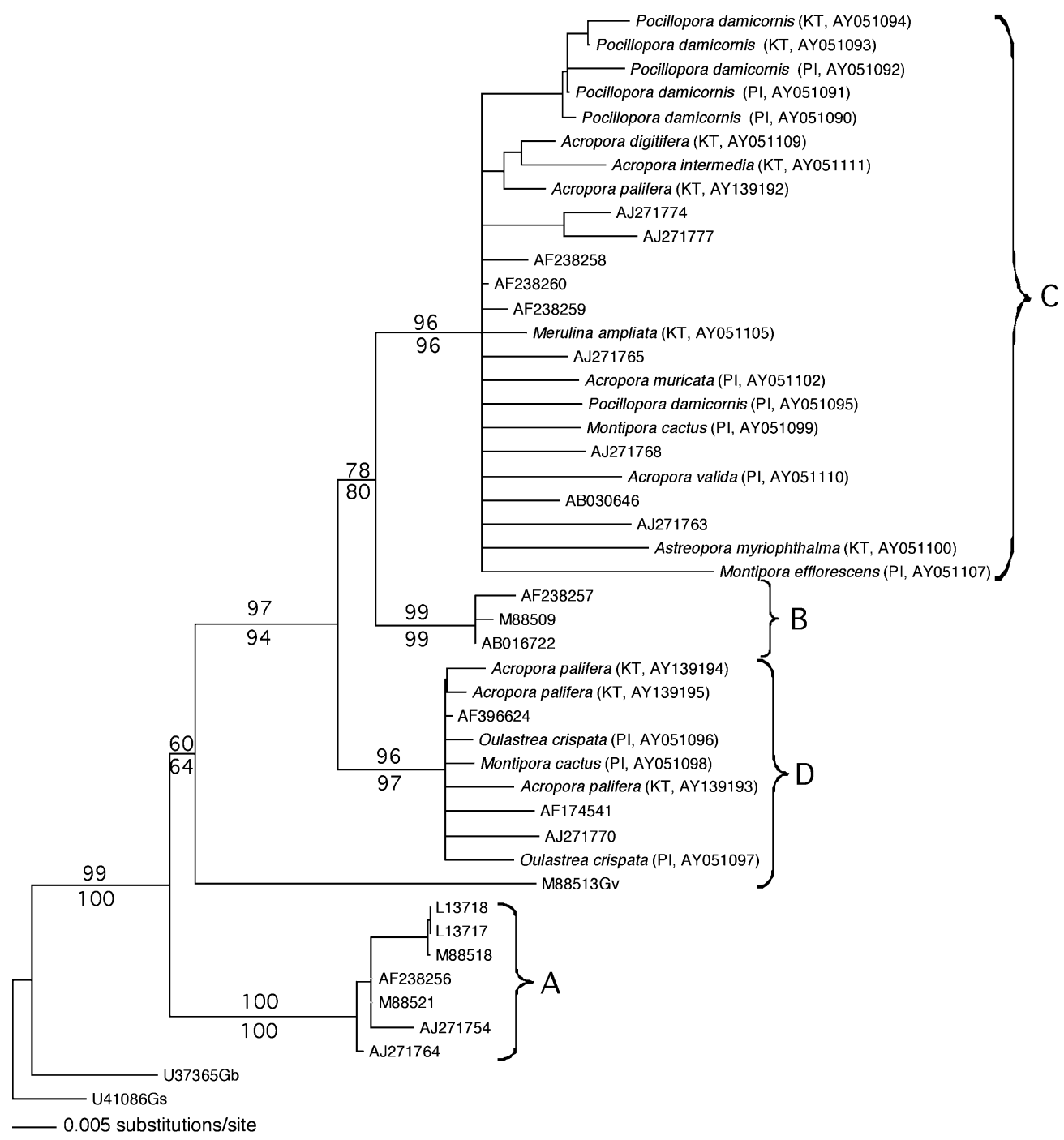

Within-clade genotypes were detected for both Symbiodinium clade $\mathrm{C}$ and $\mathrm{D}$, either in the same colony of Pocillopora damicornis $\left(\mathrm{C}_{1}\right.$ and $\left.\mathrm{C}_{2}\right)$ and Acropora palifera $\left(\mathrm{D}_{1}\right.$ and $\left.\mathrm{D}_{2}\right)$, or between different species of corals $\left(\mathrm{C}_{1}\right.$ and $\left.\mathrm{C}_{3}\right)$. For the cases of $\mathrm{C}_{1} / \mathrm{C}_{2}$ and $\mathrm{D}_{1} / \mathrm{D}_{2}$, although within colonial polymorphism may represent two different Symbiodinium genotypes present in the colonies, the equal parsimonious explanation is that there is only a single genotype of Symbiodinium present in each of these colonies, and that this genotype contains heterogenous copies of nssrDNA (reviewed in Rowan 1998; Toller et al. 2001a). The rDNA is a multigene family in eukaryotes, and rDNA heterogeneity has been reported to occur in single individuals, including dinoflagellates (Scholin et al. 1993; Scholin and Anderson 1994, 1996), and among gene-family members (reviewed in Hillis and Dixon 1991). In contrast, $C_{1}$ and $C_{3}$ may represent distinct Symbiodinium within clade C, because (1) $\mathrm{C}_{1}$ and $\mathrm{C}_{3}$ did not co-occur within the same colony of corals (except that in A.palifera), and (2) $\mathrm{C}_{3}$ was only found in Acropora spp. and Galaxea fasicularis in our survey
(Table 1). Sequencing the ITS and clsrDNA are currently underway to examine the status of $\mathrm{C}_{1}$ and $\mathrm{C}_{3}$.

Symbiosis polymorphism of Symbiodinium clade C and D: Implications for the stress-tolerance hypothesis

Symbiosis polymorphism of different zooxanthellae clades was first described in the sibling Caribbean coral species, Montastrea annularis and M. faveolata (Rowan and Knowlton 1995). Both species are associated with Symbiodinium clade A, B, and C on an offshore reef of San Blas Island, Panama, but another species, $M$. franksi, hosts only Symbiodinium clade C. Symbiodinium clade $\mathrm{A}$ and $\mathrm{B}$, either singly or in combination, are predominant in shallow-water colonies or on colony tops (with high irradiance), and clade $\mathrm{C}$ is predominant in deep-water colonies or on colony sides (with low irradiance). Mixtures of Symbiodinium clade A and/or B with $\mathrm{C}$ occur between the two extremes (Rowan and Knowlton 1995; Rowan et al. 1997). Rowan et al. (1997) 
Fig. 3 (Contd.)

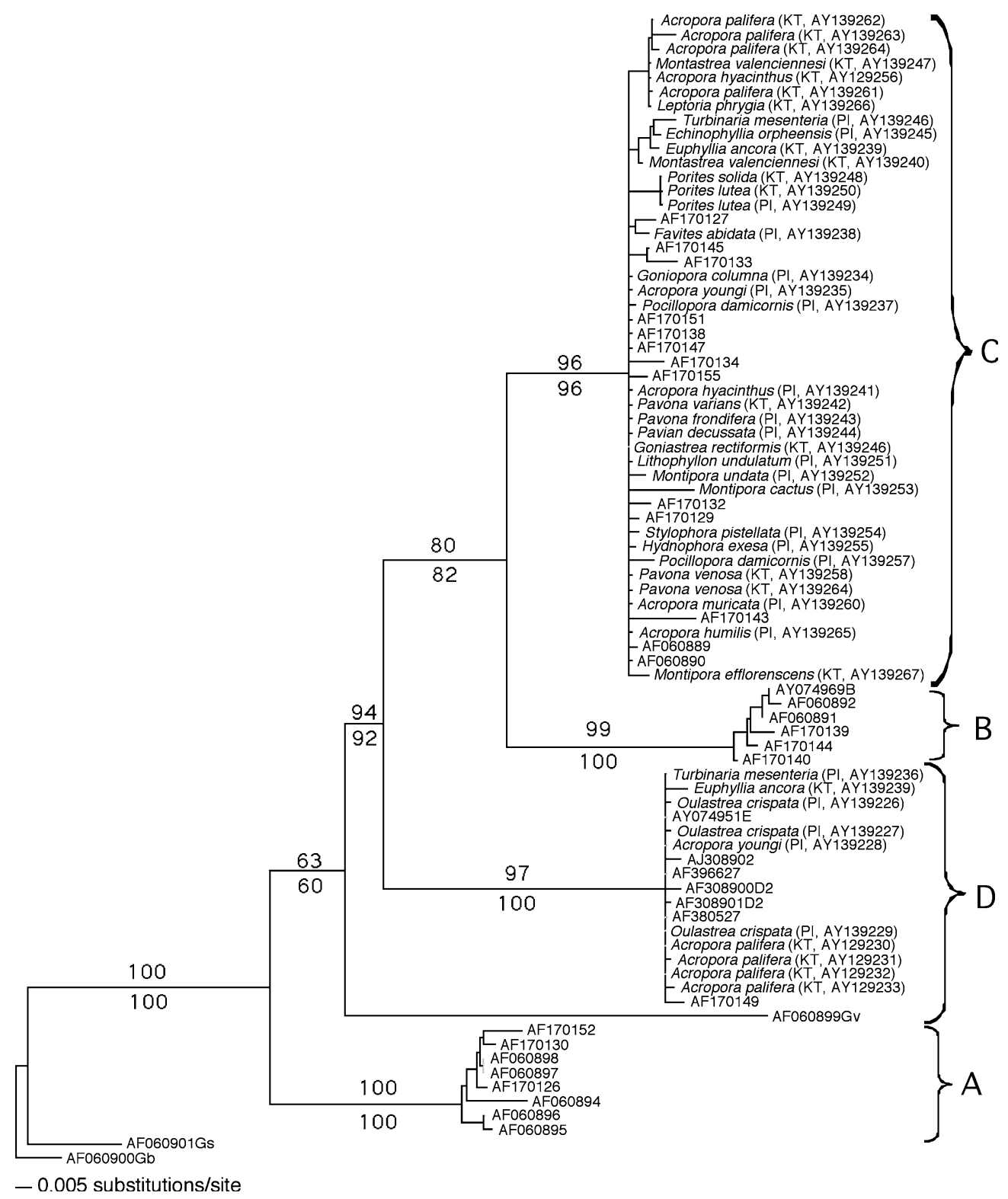

found evidence to suggest that some corals can adapt to changing environmental conditions by altering their symbiont genotype composition and distribution along

Table 2 Comparison of zooxanthellae diversity in scleractinian corals from southern Taiwan (Kenting) and Penghu

\begin{tabular}{llll}
\hline & \multicolumn{3}{l}{ Symbiodinium clade } \\
\cline { 2 - 4 } Locality $^{\mathrm{a}}$ & $\mathrm{C}^{\mathrm{b}}$ & $\mathrm{D}^{\mathrm{c}}$ & $\mathrm{C}+\mathrm{D}^{\mathrm{d}}$ \\
\hline Kenting & 29 & 0 & 2 \\
Penghu & 22 & 1 & 5 \\
\hline
\end{tabular}

${ }^{\mathrm{a}} X^{2}$ test $=2.742$, d.f. $=2, p>0.05$

${ }^{b}$ Number of coral species associated with Symbiodinium clade C only

${ }^{\mathrm{c}}$ Number of coral species associated with Symbiodinium clade D only

${ }^{\mathrm{d}}$ Number of coral species associated associated with Symbiodinium clade $\mathrm{C}$ or $\mathrm{D}$, or $\mathrm{C}$ and $\mathrm{D}$ simultaneously large coral colonies. Subsequently, in a survey of inshore reefs, Symbiodinium clade D was identified by analyses of nssrDNA RFLP and sequences (Toller et al. 2001a). Symbiodinium clade D predominated in higher-irradiance habitats in M. franksi and its two sibling species. In contrast, offshore M. franksi mainly hosted Symbiodinium C, but hosted Symbiodinium clade A, B, C, and D in shallow water and D and C in very deep water (Toller et al. 2001a). Based on circumstantial evidence, Symbiodinium clade D was hypothesized to be relatively stress tolerant (Toller et al. 2001a).

The symbiosis polymorphism found in seven species of scleractinian coral in the present study was comprised of Symbiodinium clade C and D. Our results support the hypothesis that Symbiodinium clade D is a relatively stress-tolerant zooxanthellae among the four Symbiodinium clades. First, Symbiodinium clade D was originally found either along the coast near a large river where 
Table 3 List of scleractinian corals known to be associated with Symbiodinium D, collecting localities and depth, and references

\begin{tabular}{|c|c|c|c|}
\hline Host species & Locality & Depth (m) & Reference \\
\hline \multirow[t]{2}{*}{ Acropora palifera } & Kenting, Taiwan & $0-2$ & This study \\
\hline & Guam, Micronesia & - & Pochon et al. 2001 \\
\hline Euphyllia ancora & Kenting, Taiwan & $12-15^{\mathrm{a}}$ & This study \\
\hline E. paraancora & Penghu, Taiwan & $8-12^{\mathrm{a}}$ & This study \\
\hline Favites abidata & Penghu, Taiwan & $1-3$ & This study \\
\hline Goniastrea aspera & Thailand & - & Brown et al. 2000 \\
\hline M. faveolata & San Blas, Panama & $1-3 ; 3-6^{\mathrm{b}}$ & Toller et al. 2001a \\
\hline M. franksi & San Blas, Panama & $1-3 ; 3-6^{\mathrm{b}} ; 35-38^{\mathrm{a}}$ & Toller et al. 2001a \\
\hline Montipora patula & Guam, Micronesia & - & Rowan and Powers 1991a \\
\hline M. cactus & Penghu, Taiwan & $1-3$ & This study \\
\hline Pavona decusata & Guam, Micronesia & - & Pochon et al. 2001 \\
\hline Pocillopora elegans & East Pacific & - & Baker 1999 \\
\hline
\end{tabular}

- Data not available

${ }^{a}$ On the margin of the reef topology at that locality

${ }^{\mathrm{b}}$ The tops of colonies were at 3-6 $\mathrm{m}$ in depth

corals reefs are poorly developed only at a great depth where coral colonies are not large, and where the reef itself disappears into the sediment (Table 3, Toller et al. 2001a). In southern Taiwan and Penghu, scleractinian corals hosting Symbiodinium clade D were either from very shallow water or at the margin of the reef at each locality (Table 3). For example, Acropora palifera occurred at the lower intertidal zone of the fringing reef off Kenting, southern Taiwan, where physical disturbance is high, and Euphyllia ancora was only found at depths of $12-15 \mathrm{~m}$ on the fringing reef, where the reef enters into the sandy bottom (Dai 1991). In Penghu, scleractinian corals are usually limited to depths of less than $10 \mathrm{~m}$ due to the harsher environmental conditions than in southern Taiwan (Hsieh et al. 2001; Chen et al. 2003). Coral species associated with Symbiodinium clade D occurred either in very shallow water ( $A$. youngi, Favites abidata, Montipora cactus, and Oulastrea crispata) or at the edge of reefs (Euphyllia paraancora and Turebinaria mensenteria). The other Indo-Pacific species associated with Symbiodinium clade D also occur in shallow water (Veron 2000), although no depths were recorded in the original references (Table 3). The second piece of evidence supporting Symbiodinium clade D being relatively stress-tolerant zooxanthellae is the obligate association of Symbiodinium clade D with O. crispata. Oulastrea crispata is distributed from the tropical Indo-West Pacific to high latitudes around Japan (Veron 1993), implying that $O$. crispata can cope with a wide range of ecological variation over a large geographic scale. At the local scale, O. crispata is only found in extreme environments. Oulastrea crispata occurs commonly on shallow reef depressions and on turbid bay bedrocks inhabited by only a few other corals (Nakano and Yamazato 1992; Lam 2000; personal observation).
These corals, including Porites lutea, Goniopora columna, G. lobata, and Lithophyllon undulatum, were associated with Symbiodinium clade C (Table 1). A temperature recorder located at the collecting site in Penghu indicated that water temperatures in the area where $O$. crispata lived fluctuated enormously, ranging from $12{ }^{\circ} \mathrm{C}$ in winter to $35{ }^{\circ} \mathrm{C}$ in summer (Chen et al. 2004). In addition, $O$. crispata is also a coral colonizing artificial substrates where environmental disturbance is high (Lam 2000). In the high latitudes of Japan, O. crispata can be found in habitats where winter water temperatures are usually 7 to $10{ }^{\circ} \mathrm{C}$ and air temperatures are several degrees below freezing for about 20 days/year (Yajima et al. 1986). Spatial and temporal surveys of zooxanthellae diversity in Hong Kong and Penghu have demonstrated that Symbiodinium clade D is the only clade of zooxanthellae found within $O$. crispata (Chen et al. 2003). These findings suggest that associating with a stress-tolerant symbiont, such as Symbiodinium clade $\mathrm{D}$, may help $O$. crispata survive harsh environments. Further experiments on the physiology of both $O$. crispata and Symbiodinium clade D are needed to confirm this scenario.

In conclusion, a survey of 52 species of scleractinian corals from a tropical reef and a subtropical non-reefal coral community indicated that no apparent variation in zooxanthellae diversity exists between these two coral communities in Taiwan. RFLPs and phylogenetic analyses of nuclear-encoded ribosomal RNA genes show that Symbiodinium clade C is the dominant zooxanthellae in scleractinian corals in the seas around Taiwan, while the other zooxanthellae clade were from Symbiodinium clade D. Symbiosis polymorphism was found in seven species of scleractinian corals and is comprised of Symbiodinium clade C and D. The scleractinian corals 
associated with Symbiodinium clade D live either in shallow water or at the edge of reefs in deep water, supporting the hypothesis that Symbiodinium clade D is a relatively stress-tolerant zooxanthellae of marginal habitats.

Acknowledgments Many thanks to J.-K. Yu, K. M. Lin, and K. A. Chen for laboratory assistance, and to the staff of the Penghu Aquarium, a facility of the Taiwan Fishery Research Institute, for providing hospitality during field trips. We thank C.-F. Dai, H. J. Hsieh, two anonymous reviewers, and members of the Evolution and Ecology Discussion Group, Institute of Zoology, Academia Sinica (IZAS), for constructive comments. This is Evolution and Ecology Group, IZAS Contribution No. 22. This work was supported by grants from IZAS and the National Science Council, Taiwan to C.A.C. and L.S.F.

\section{References}

Baker AC (2001) Reef corals bleach to survive change. Nature 411:765-766

Baker AC, Rowan R (1997) Diversity of symbiotic dinoflagellates (zooxanthellae) in scleractinian corals of the Caribbean and eastern Pacific. Proc 8th Int Coral Reef Symp 2:1301-1306

Baker AC, Rowan R, Knowlton N (1997) Symbiosis ecology of two Caribbean acroporid corals. Proc 8th Int Coral Reef Symp 2:1295-1300

Ballie BK, Belda-Ballie CA, Maruyama Y (2000) Conspecificity and Indo-Pacific distribution of Symbiodinium genotypes (Dinophyceae) from giant clams. J Phycol 36:1153-1161

Barnes DJ, Chalker BE (1990) Calcification and photosynthesis in reef-building corals and algae. In: Dubinsky Z (ed) Ecosystems of the world, vol 25. Coral Reefs. Elsevier, New York, pp 109131

Carlos AA, Baillie BK, Kawachi M, Maruyama T (1999) Phylogenetic position of Symbiodinium (Dinophyceae) isolates from tridacnids (Bivalvia), cardiids (Bivalvia), a sponge (Porifera), a soft coral (Anthozoa), and a free-living strain. J Phycol 35:1054-1062

Chen CA (1999) Analysis of scleractinian distribution in Taiwan indicating a pattern congruent with sea surface temperature and currents: examples from Acropora and Faviidae. Zool Stud 38:119-129

Chen CA, Lam KK, Nakano Y, Tsai WS (2003) A stable association of a stress-tolerant zooxanthellae, Symbiodinium clade D, with the low-temperature tolerant coral, Oulastrea crispata, (Scleractinia; Faviidae) in the subtropical non-reef coral communities. Zool Stud 42:540-550

Chen CA, Wallace CC, Yu JK, Wei NV (2000). Strategies for amplification by polymerase chain reaction of the complete sequence of the gene encoding nuclear large subunit ribosomal RNA in corals. Mar Biotech 6:558-570

Chen CA, Yu JK (2000) Universal primers for amplification of mitochondrial small subunit ribosomal RNA-encoding gene in scleractinian corals. Mar Biotech 2:146-153

Dai CF (1991) Reef environment and coral fauna of southern Taiwan. Atoll Res Bull 354:1-24

Dai CF (1997) Assessment of the present health of coral reefs in Taiwan. In: Grigg RR, Birkeland (eds) Status of coral reefs in the Pacific. University of Hawaii, Honolulu, pp 123-131

Darius HT, Dauga C, Grimont PAD, Chungue E, Martin PMV (2000) Diversity in symbiotic dinoflagellates (Pyrrhophyta) from seven scleractinian corals: restriction enzyme analysis of small subunit ribosomal RNA genes. J Eukaryot Microbiol 45:619-627

Falkowski PG, Dubinsky Z, Muscatine L, Porter JW (1984) Light and bioenergetics of a symbiotic coral. Bioscience 34:705709
Gilbert DC (1994) SeqApp 1.9. A biological sequence editor and analysis program for Macintosh computers. Available at http:// www.ftp.indiana.edu.tw

Hillis DM, Dixon MT (1991) Ribosomal DNA: molecular evolution and phylogenetic inference. Q Rev Biol 66:411-453

Hsieh HJ, Wei NV, Lu YL, Jeng MS, Tsai WS, Chen CA (2001) An unexpected high coral coverage in Chinwan Inner Bay, Pescadores: a potential site for Marine Protection Area. Coral Reefs 20:316-317

Hunter CL, Morden CW, Smith CM (1997) The utility of ITS sequences in assessing relationship among zooxanthellae and corals. Proc 8th Int Coral Reef Symp 2:1599-1602

LaJeunesse TC (2001) Investigating the biodiversity, ecology, and phylogeny of endosymbiotic dinoflagellates in the genus Symbiodinium using the internal transcribed spacer region: in search of a "species" level marker. J Phycol 37:866-880

Lam KK (2000) Sexual reproduction of a low temperature tolerant coral, Oulastrea crispata, in Hong Kong, China. Mar Ecol Prog Ser 205:101-111

Loh WKW, Loi T, Carter D, Hoegh-Guldberg O (2001) Genetic variability of the symbiotic dinoflagellates from the wide ranging coral species, Seriatopora hystrix and Acropora longicyathus, in the Indo-West Pacific. Mar Ecol Prog Ser 222:97107

Muller-Parker G, D'Elia C (1997) Interactions between corals and their symbiotic algae. In: Birkeland $\mathrm{C}$ (ed) Life and death of coral reefs. Chapman and Hall, New York, pp 96-113

Muscatine L, Porter JWP (1977) Reef corals: mutualistic symbioses adapted to nutrient-poor environments. Bioscience 27:454 460

Nakano Y, Yamazato K (1992) Ecological study of reproduction of Oulastrea crispata in Okinawa. Zool Sci 9:1292

Pawlowski J, Holzmann M, Fahrni J, Pochon X, Lee JJ (2001) Molecular identification of algal endosymbionts in large miliolid foraminifera. 2. Dinoflagellates. J Eukaryot Microbiol 48:368-373

Pochon X, Pawlowski J, Zaninetti L, Rowan R (2001) High genetic diversity and relative specificity among Symbiodinium -like endosymbiotic dinoflagellates in soritid foraminiferans. Mar Biol 139:1067-1078

Rodriguez-Lanetty M, Loh W, Carter D, Hoegh-Guldberg O (2001) Latitudinal variability in symbiont specificity within the widespread scleractinian coral Plesiastrea versipora. Mar Biol 138:1175-1181

Rowan R (1998) Diversity and ecology of zooxanthellae on coral reefs. J Phycol 34:407-417

Rowan R, Knowlton N (1995) Intraspecific diversity and ecological zonation in coral-algal symbiosis. Proc Natl Acad Sci USA 92:2850-2853

Rowan R, Knowlton N, Baker A, Jara J (1997) Landscape ecology of algal symbionts creates variation in episodes of coral bleaching. Nature 388:265-269

Rowan R, Powers DA (1991a) Molecular genetic identification of symbiotic dinoflagellates (zooxanthellae). Mar Ecol Prog Ser 71:65-73

Rowan R, Powers DA (1991b) A molecular genetic classification of zooxanthellae and the evolution of animal-alga symbioses. Science 251:1348-1351

Saitou N, Nei M (1987) The Neighbor-joining method: a new method for reconstructing phylogenetic trees. Mol Biol Evol 4:406-425

Santos SR, Taylor DJ, Kinizie RA III, Hidaka M, Sakai K, Coffroth MA (2002) Molecular phylogeny of symbiotic dinoflagellates inferred from partial chloroplast large subunit (23S)rDNA sequences. Mol Phylogenet Evol 23:97-111

Scholin CA, Aderson DM (1996) LSU rDNA-based RFLP assays for discriminating species and strains of Alexandrium (Dinophyceae) J Phycol 32:1022-1035

Scholin CA, Anderson DM, Sogin ML (1993) Two distinct smallsubunit ribosomal RNA genes in the North American toxic dinoflagellate Alexandrium fundyense (Dinophyceae). J Phycol 29:209-216 
Scholin CA, Anderson DM (1994) Identification of group- and strain-specific genetic markers for globally distributed Alexandrium (Dinophyceae) I. RFLP analysis of SSU rRNA gene. J Phycol 30:744-754

Shao KT, Chen JP, Ho LT, Lin CP, Kao PH, Lin PL, Chen LS (1994) Checklist and distribution of the fishes of the Pescadores Islands. Proc. 4th Indo-Pacific Fish Conf Kasetart Univ., Bangkok, Thailand, pp 267-280

Swofford DL (2002) PAUP 4.10b: phylogenetic analysis using parsimony (and other methods). Sinauer Associates, Sunderland, MA

Tamura K, Nei M (1993) Estimation of the number of nucleotide substitutions in the control region of mitochondrial DNA in humans and chimpanzees. Mol Biol Evol 10:512-526

Taylor DL (1974) Symbiotic marine algae: taxonomy and biological fitness. In: Vernberg WB (ed) Symbiosis in the sea. Univ. of South Carolina Press, Columbia, SC, pp 245-262

Thompson JD, Higgins DG, Gibson TJ (1994) CLUSTAL W: improving the sensitivity of progressive multiple sequence alignment through sequence weighting, position-specific gap penalties and weight matrix choice. Nucl Acids Res 22:46734680

Toller WW, Rowan R, Knowlton N (2001a) Zooxanthellae of the Montastraea annularis species complex: patterns of distribution of four taxa of Symbiodinium of different reefs and across depths. Biol Bull 201:348-359

Toller WW, Rowan R, Knowlton N (2001b) Repopulation of zooxanthellae in the Caribbean corals Montastraea annularis and $M$. faveolata following experimental and disease-associated bleaching. Biol Bull 201:360-373

Trench R (1997) Diversity of symbiotic dinoflagellates and the evolution of microalgal-invertebrate symbioses. Proc 8th Int Coral Reef Symp 2:1275-1286 van Oppen MJH, Palstra FP, Piqet AM-T, Miller DJ (2001) Patterns of coral-dinoflagellate associations in Acropora: significance of local availability and physiology of Symbiodinium strains and host-symbiont selectivity. Proc R Soc Lond B 268:1579-1767

Veron JEN (1993) Coral of Australia and the Indo-Pacific. Univ. of Hawaii Press, NSW, Australia

Veron JEN (1995) Corals in space and time: the biogeography and evolution of the Scleractinia. Univ. New South Wales Press, Sydney, Australia

Veron JEN (2000) Corals of the world. Australian Institute of Marine Science, Townsville, Australia

Veron JEN, Minchin PR (1992) Correlations between sea surface temperature, circulation patterns, and the distribution of hermatypic corals of Japan. Cont Shelf Res 12:835-857

Wilcox TP (1998) Large-subunit ribosomal RNA systematics of symbiotic dinoflagellates: morphology does not recapitulate phylogeny. Mol Phylogenet Evol 10:436-448

Yajima T, Osamie S, Okamoto T, Yoshohiro S, Thutomu S, Masahiro M (1986) Ecological distribution of the reef coral, Oulastrea crsipata (Larmack) at the shore region in the vicinity of Tsukumo Bay. Bull Jpn Sea Res Inst Kanazawa Univ 18:2136

Yu JK, Liao TH, Fang LS, Tsai WS, Chen CA (2000) Do color patterns of Pocillopora damicornis correlate with zooxanthellae diversity? Coral Reefs 19:98-99

Yu JK, Wang HY, Lee SC, Dai CF (1999) Genetic structure of a scleractinian coral, Mycedium elephantotus, in Taiwan. Mar Biol 133:21-28 